\title{
What Explains the Financing Behavior of Commercial Banks Listed on the Kuwait Stock Exchange: The Pecking Order Theory or Trading Off Theory
}

\author{
Dr. Tharwah Shaalan \\ Assistant Professor in Finance, Tiabah University, Department of Finance \& Economics \\ Corresponding author - tshaalan@ taibahu.edu.sa
}

Received 17 October 2019;

Accepted 26 October 2019;

Published 17 November 2019

\begin{abstract}
This paper seeks to investigate which theory explains the capital structure of the commercial banks listed in the Kuwait stock markets: the pecking order theory or the tradeoff theory. The study used time series and cross-section panel data to test the hypothesis. The data spanned over a period of nine years from 2010-2018, using all commercial banks listed in the Kuwait stock market. The results showed that the trade-off theory is the best theory to conduct the capital structure of the Kuwaiti commercial banks while the pecking order theory presents a weak from. The paper proved that there was no heteroscedasticity in cross-sectional data nor auto correlation over the time series panel model.
\end{abstract}

Keywords: Pecking order theory, trade-off theory, cross-sectional, time series, panel data, Kuwaiti banks

Gel code: C31,C32,21,G32

\section{Literatures Review}

According to the First Proposition of M \&M (1958), borrowing has no effect on the market value of the firm under full market conditions, as the value of the firm depends on the ability of its assets to generate profits. The first theory of M\&M states that if the hypothesis of no taxes is dropped, the market value of a firm that relies on debt and equity is higher than the value of a firm based on equity alone.

In M\&M theory two (1963), stated that the cost of equity increased directly with the leverage measured by the debt to equity ratio, where the cost of equity of the leveraged firm exceeded the cost of equity of the unleveraged firm.

Myers (1984) showed that there has been little research interest in whether the relationship between leverage and the required return on investors is as pure as the M\&M theory predicts. On the whole, we have insufficient understanding of corporate finance behavior and how this behavior affects security returns.

Myers (1984) compared two theories of capital structure, the static trade-off theory in which the firm targets the debt ratio; the other is the pecking order theory in which the firm prefers internal financing to external financing and prefers borrowing than issuing new securities.

Myers and Sunder (1999) applied the framework for testing the two theories. they scrutinized financing structure against the picking of funding sources, wherein the firm relies on internal sources of funding, such as retained earnings, because it is the least expensive source of financing, then debt, and finally, stocks, because they are the most expensive. The results illustrated the explanatory power of the funding source prioritization model of the trading model, which predicts that each company adapts to the optimal debt ratio.

\section{Imperial Studies}

Furthermore, Myers (2001) talked about the same context in (1984) and reviewed the M \&M theory (1958), in which the capital structure has no effect on the firm value, and the correction of M\&M theory (1963). The value of unleveraged firm equals the value of leveraged firm plus the tax shield.

Frank and Goyal (2003) examined the pecking order theory on a wider range of firms and for a longer period. The sample included 768 firms for the period 1971-1998. Their results differed from those of Shyam-Sunder and Myers (1999). While firms use external financing, the preference for debt is not evident. With the same model, restrictions and time period (as was the case in Shyam-Sunder and Myers, 1999), Frank and Goyal (2003) found the beta coefficient and coefficient of determinations to be lower for the range of firms. They reported that the pecking order theory performs best among the largest firms. Also, a sub-sample of firms with strictly positive dividends produces a relatively high beta coefficient and explanatory power. Furthermore, this was also recommended by Shyam-Sunder and Myers (1999) who argued that low $\mathrm{R}^{2}$ in 1980 s is explained by firms undertaking leveraged restructurings. Thus, it seems that the pecking order theory does well among large and stable firms.

Bharath et al. (2009) studied the financing behavior of US firms for the period 1973-2002. They used an information asymmetry index as an additional variable in the standard financial deficit-based model. They found that information asymmetry does 
indeed increase the clarifying power of the standard pecking order model.

Jibran et al. (2012) examined the theory of capital structure of listed companies in Pakistan. According to the pecking order theory, the resources generated internally will be the priority, followed by debt issuance where equity is used as a last resource. In its strong form, the pecking order theory confirms that equity issues will never happen, whereas in its weak form, limited amounts of cases are acceptable. The methodology adopted in this the experimental study includes cross-section regressions and test hypotheses based on the basic theory in its strong and weak forms. The value of R2, t-test and F-Stat indicates that companies on KSE support the weak form of the pickup order theoretically, the use of internal equity and debt is preferred and limited external equity is used for reinvestment and fund-raising.

However, Rahman, Arifuzzaman (2014) verified two models of capital structure using the Shyam-Sunder and Myers approach (1999) to find the behavior of the capital structure of UK companies, whether companies followed the pecking order model or the trade-off model. The sample size consisted of 60 companies and 51 companies; the observation period extended from 1992, 2012 and 1995-2012. Using plate data regression in size and two samples, the investigational results showed that both models are not suited for giving any convincing result of the behavior of the capital structure of UK companies.

Al-Momani and Obeisant (2017) studied objects for the investigation of the most important internal determinants of the leverage of industrial companies listed on the Amman Stock Exchange (ASE). The study showed that liquidity, profitability and tangible assets have a significant impact on the instability of profits, as they did not affect the other independent variables considered by the study.

Yinusa et al. (2017) examined the rapidity and cost of adaptation to the selection of the target capital structure of Nigerian companies of 115 Nigerian non-financial companies listed in the Nigerian Stock Exchange, from 1998 to 2012. The main finding of the study indicates that there are negative relationships between rapidity and adjustment costs of companies in Nigeria because companies in emerging markets such as Nigeria are adapting moderately faster to their target debt.

Yuan's study (2018) tested the pickup order theory on Chinese companies trading in the industrial sector. Using a panel of 1212 observations between 2013 and 2015, the study concluded that there is no evidence to support the theory.

\section{Methodology and Data}

According to Sunder and Myers, the pecking order theory aims to test:

$\mathrm{D}_{\mathrm{it}}=\alpha+\beta \mathrm{DEF}_{\mathrm{it}}+\varepsilon_{\mathrm{it}}$

where $\Delta \mathrm{D}$ it presents change in debt issues by firm i in year $\mathrm{t}$. Since Kuwaiti commercial banks do not have long-term debt, we define $\Delta \mathrm{D}_{\mathrm{it}}$ as the change of short-term loan; $\varepsilon_{\text {it }}$ is the error.

DEF it is the flow of fund deficit defined as follows:

$\mathrm{DEF} t=\mathrm{DIV} t+\mathrm{Xt}+\Delta \mathrm{Wt}-\mathrm{Ct}$

where

DIV $_{t}$ : the payments for dividends.
$\mathrm{X}_{\mathrm{t}}$ : capital expenditure in year $\mathrm{t}$

$\mathrm{W}_{\mathrm{t}}$ : the change in the working capital and working capital is the difference between current assets and current liabilities) in year $t$

$\mathrm{C}_{\mathrm{t}}$ : net income after tax in year $\mathrm{t}$.

The long-term debt is also a component in financing deficit.

Sunder and Myers assumed that $(\alpha=0)$ and $(\beta \mathrm{DEF}=1)$

According to Sunder and Myers, the static trade-off theory also tests

$\mathrm{D}$ it $=\alpha+\beta\left(\mathrm{D}^{*}\right.$ it $-\mathrm{D}$ it -1$)+\varepsilon$ it

where $\mathrm{D}^{*}$ is the target debt level for firm $\mathrm{i}$ at time $\mathrm{t}$.

We can express our hypothesizes as follows:

1- $\alpha=0$ (pecking order theory assumption)

2- $\quad \beta=1$ (pecking order theory assumption)

3- The fixed effect model is appropriate to explain the pecking order theory.

4- The fixed effect model is appropriate to explain the static trade-off theory.

5- There is no heteroscedasticity nor auto correlation through time series and cross sectional panel multiregression fixed model.

Our test used seven commercial banks listed in Kuwaiti stock market covering a time period of nine years from 2010-2018.

The cross-sectional and time series panel technique was used to test our hypothesis through Stata V.14.

\section{Findings}

Our test hypothesis found that $\alpha=0$ (pecking order theory assumption) is rejected, while $\alpha \neq 0$, aequaled (119.06) in the fixedeffect model and (101.7) the random-effect model; therefore, we accepted the alternative hypothesis that $\alpha \neq 0$. Table (1) explains this result.

We rejected the second hypothesis that $\beta=1$ (pecking order theory assumption). Table (1) shows that the beta coefficients in random and fixed effect model equaled 0.23 and 0.09 respectively.

We accepted the null hypothesis that the fixed effect model is an appropriate model to explain the pecking order theory. The overall R-sq equals (0.22) and the beta's significance of the pecking order coefficient equals (0.078); the Hausman test result in Table (2) shows Prob $>$ chi $2=0.000<0.05$. This means that the fixed-effect model is the best model to explain the pecking order theory.

Furthermore, we accepted the null hypothesis that the fixed effect model is an appropriate model to explain the trade-off theory. The overall R-sq (0.86) and the significance of beta and alfa equaled 0.000 and 0.03 respectively, as shown in Table (4). The Breusch and Pagan Lagrangian multiplier test for random effects in Table (5) explains that the fixed effect is the appropriate model to interpret the trade-off theory, while the Prob $>$ chibar $2=$ $1>0.05$, the results of heteroscedasticity and auto-correlation through time series and cross-sectional panel multi-regression fixed model of pecking order theory and trade-off theory models' summary is illustrated in tables (3) and (5); Prob > chi2 equaled $(0.0002)$ for the two-model test of pecking order and trade-off theory. Therefore, we can accept the null hypothesis while the Prob $>\operatorname{chi} 2<0.05$. 
Table (1): Comparison between random and fixed effect model to test pecking order theory

\begin{tabular}{|l|l|l|l|l|l|}
\hline Model & within & between & overall & corr(u_i, X) (assumed) & \\
\hline Random effects & 0.055 & 0.931 & 0.2202 & 0 & \\
\hline Fixed effects & 0.055 & 0.931 & 0.2202 & 0.4444 & \\
\hline Random effects & \multicolumn{5}{|l|}{} \\
\hline Debt & Coef. & P>z & Fixed effects & Coef. & $0.078^{*}$ \\
\hline Def & .233 & $0.000^{* * *}$ & .09109 & $0.000^{* * *}$ \\
\hline cons & 101.7 & $0.000^{* * *}$ & 119.06 & F.e.120.75 \\
\hline R e. sigma_u & 0 & F.e.123.94 & \\
\hline R e. signage & 123.94 & F.e.0.48697 & \\
\hline R.e. rho & 0 & &
\end{tabular}

*** P<0.01, **P<0.05, *P<0.1

Table (2): Hausman test

\begin{tabular}{|l|l|l|l|l|}
\hline Coefficients & (b) & (B) & (b-B) & Sqrt (diag (V_b-V_B)) \\
\hline & $\operatorname{Re}$ & f e & Difference & S.E. \\
\hline DEF & .2339 & .091 & .142846 & .0245 \\
\hline $\begin{array}{l}\text { Test: Ho: } \\
\text { chi2(4) }=\left(\text { b-B) }\left[\left(V_{-} \text {b-V_B }\right)^{\wedge}(-1)\right](b-B)\right.\end{array}$ \\
Prob>chi2 $=0.000$
\end{tabular}

Table (3): Cross-sectional time-series FGLS regression to test pecking order theory

\begin{tabular}{|c|c|c|c|}
\hline \multicolumn{4}{|c|}{ Coefficients: generalized least squares } \\
\hline \multicolumn{4}{|l|}{ Panels: homoscedastic } \\
\hline \multicolumn{2}{|l|}{ Correlation: panel-specific AR(1) } & \multicolumn{2}{|c|}{ Number of obs $=63$} \\
\hline \multicolumn{2}{|l|}{ Estimated covariances $=1$} & \multicolumn{2}{|c|}{ Number of groups $=7$} \\
\hline \multicolumn{2}{|l|}{ Estimated autocorrelations $=7$} & \multicolumn{2}{|c|}{ Time periods $=9$} \\
\hline \multicolumn{2}{|l|}{ estimated coefficients $=2$} & \multicolumn{2}{|c|}{ Prob > chi $2=0.0002$} \\
\hline Debt & Coef. & Std. Err. & $\mathrm{P}>|\mathrm{z}|$ \\
\hline DEF & .08326 & .0223 & 0.000 \\
\hline Cons & 84.1472 & 39.93 & 0.035 \\
\hline
\end{tabular}

$* * * P<0.01, * * P<0.05, * P<0.1$

Table (4): Comparison between random and fixed effect model to test the static trade-off theory

\begin{tabular}{|c|c|c|c|c|c|}
\hline Model R-sq: & within & between & overall & corr $\left(u_{-} i, \mathbf{X}\right)$ (assumed) & Prob of chi 2 and $F$ \\
\hline Random effects & 0.7573 & 0.9871 & 0.8626 & 0 & Prob $>$ chi $2=0.0000$ \\
\hline Fixed effects & 0.7573 & 0.9871 & 0.8626 & 0.6103 & Prob $>F=0.0000$ \\
\hline Random effects & & & & \multicolumn{2}{|l|}{ Fixed effects } \\
\hline Debt & Coef. & \multicolumn{2}{|l|}{$\mathrm{P}>\mathrm{z}$} & Coef. & $\mathrm{P}>\mathrm{t}$ \\
\hline dDebt & 1.094 & \multicolumn{2}{|l|}{$0.000 * * *$} & .95779 & $0.000 * * *$ \\
\hline Cons & 10.05 & \multicolumn{2}{|l|}{0.327} & 25.082 & $0.030 * *$ \\
\hline R e. sigma_u & & & & \multicolumn{2}{|l|}{ F. e. 35.672} \\
\hline R e. sigma & & & & \multicolumn{2}{|l|}{ F.e. 62.825} \\
\hline R.e. rho & & & & \multicolumn{2}{|l|}{ F. e. 0.2437} \\
\hline
\end{tabular}

Table (5): Breusch and Pagan LaGrange multiplier test for random effects

\begin{tabular}{|l|l|l|}
\hline Debt[BID,t] $=\mathrm{Xb}+\mathrm{u}[\mathrm{BID}]+\mathrm{e}[\mathrm{BID}, \mathrm{t}]$ & $\mathrm{Sd}=\operatorname{sqrt}($ Var $)$ \\
\hline Estimated results: & Var & 174.7768 \\
\hline Debt & 30546.95 & 62.82562 \\
\hline $\mathrm{E}$ & 3947.059 & 0 \\
\hline $\mathrm{U}$ & 0 & \\
\hline Test: $\operatorname{Var}(\mathrm{u})=0$ & & \\
Prob $>$ chibar2 $=1.0000$ & & \\
\hline
\end{tabular}

Table (6): Cross-sectional time-series FGLS regression to test trade-off theory

\begin{tabular}{|l|l|}
\hline \multicolumn{2}{|l|}{ Coefficients: generalized least squares } \\
\hline Panels: homoscedastic & Number of obs $=63$ \\
\hline Correlation: panel-specific AR(1) & Number of groups $=7$ \\
\hline Estimated covariances $=1$ &
\end{tabular}




\begin{tabular}{|c|c|c|c|}
\hline \multicolumn{2}{|c|}{ Estimated autocorrelations $=7$} & \multicolumn{2}{|c|}{ Time periods $=9$} \\
\hline \multicolumn{2}{|c|}{ estimated coefficients $=2$} & \multicolumn{2}{|c|}{ Prob $>$ chi $2=0.0002$} \\
\hline Debt & Coef. & Std. Err. & $\mathrm{P}>|\mathrm{z}|$ \\
\hline $\mathrm{DEF}$ & 1.005 & .059 & 0.000 \\
\hline Cons & 51.36 & 15.85 & 0.001 \\
\hline
\end{tabular}

\section{Discussion}

Our results found positive and weak relationships between financing deficit and debt issues, and a weak frame of pecking order theory. This was due to the fact that banks rely on short-term assets and hence short-term debt by virtue of the nature of banks' activities as financial institutions; the fixed assets constitute a small percentage of total assets and investments of the bank. The overall panel $\mathrm{R} \mathrm{sq}=22 \%$ beta did not equal one and alfa did not equal zero. Sunders and Myers' assumptions about alfa and beta were found to be untrue. Our results also explored strong evidence of trade-off theory: the overall panel $\mathrm{R}$ sq explanatory power was found to be $86 \%$; so our results are consistent with the fact of low commercial profit tax rate in GCC countries. many of the companies and banks under study encourage not issuing long-term debt and retaining part of profits and distributing the other part. Our results were in agreement with Myers and Sunder's (1999) in the part about Consolidation theory, Frank and Goyal's results (2003), Jibran et al.'s (2012) and Yuan's (2018) analysis, while it contradicted Rahman, Arifuzzaman's (2014) results.

\section{Conclusion}

The Myers and Sunder's (1999) assumptions about the pecking order theory have not been achieved in many empirical studies. The studies which investigated the pecking order theory found weak forms of alfa and beta coefficient alfa not equal to zero and beta not equal to one as Myers and Sunder (1999) assumed, so I recommend a great amount of research to bring out the other assumption about alfa and beta coefficients and test the theory on a wide range of firm types. I also recommend testing the theory over longer periods of time.

\section{References}

[1] Al-Momani, M., Obeidat, M. (2017). Towards more understanding of the financial leverage controversy: The evidence of the industrial firms at Amman Stock Exchange. International Journal of Economics and Financial Issues,7(4), 189-198.
[2] Bharath, S.T., Pasquariello, P., Wu, G. (2009). Does Asymmetric Information Drive Capital Structure Decisions. Review of Financial Studies, 22(8): 32113243.

[3] Frank, M., Goyal, V. (2003). Testing the pecking order theory of capital structure. Journal of Financial Economics, 67(2), 217-248.

[4] Jibran, S., et al. (2012). Pecking at pecking order theory: Evidence from Pakistan's non-financial sector. Journal of Competitiveness, 4(4), 86-95.

[5] Modigliani, F., Miller, M. (1958). The cost of capital, corporate finance and the theory of investment. American Economic Review,48, 261-297.

[6] Modigliani, F., Miller, M. (1963). Corporate income taxes and the cost of capital. A Correction. American Economic Review, 53,433-443.

[7] Myers, S. C. (1984). The capital structure puzzle. ,The Journal of Finance. 39(3), 574-592.

[8] Myers, S. C., \& Majluf, N. S. (1984). Corporate financing and investment decisions when firms have information that investors do not have. Journal of Financial Economics, 13(2),187-221.

[9] Myers, S. C. (2001). Capital structure. Journal of Economic Perspectives, 15(2), 81-102.

[10] Shyam-Sunder, L., \& C. Myers, S. (1999). Testing static tradeoff against pecking order models of capital structure. Journal of Financial Economics, 51(2), 219244.

[11] Rahman, A., Arifuzzaman, S.M. (2014). Testing the Trade Off and Pecking Order Models of Capital Structure. Journal of Economics and Finance (IOSRJEF),5( 6), 8-14.

[12] Yinusa, O., et al. (2017). Trade-off theory of optimal capital structure and adjustment towards long run target: A dynamic panel approach. Journal of Accounting and Management, 7(2),173-181.

[13] Yuan, Y. (2018). Does the Pecking order theory apply to Chinese publicly traded companies? evidence from manufacturing sector. Modern Economy, 9, 2233-2247. 